Klinička psihologija 9 (2016), 2, 239-256

Izvorni znanstveni članak - UDK 159.942.2

DOI: 10.21465/2016-KP-2-0003

\title{
HRVATSKI PRIJEVOD \\ UPITNIKA KOGNITIVNE EMOCIONALNE REGULACIJE - SKRAĆENI OBLIK
}

\author{
Irena Mišetić \\ Klinički bolnički centar Split, Klinika za dječje bolesti \\ Spinčićeva 1, 21000 Split \\ irenamisetic@yahoo.com \\ Andreja Bubić \\ Katedra za psihologiju, Filozofski fakultet, Sveučilište u Splitu \\ Sinjska ulica 2, 21000 Split \\ abubic@ffst.hr
}

\begin{abstract}
Sažetak
Cilj ovog istraživanja bio je razvoj hrvatskog oblika Upitnika kognitivne emocionalne regulacije - skraćeni oblik i provjera nekih njegovih psihometrijskih obilježja na uzorku 206 polaznika psihoterapije ili psihološkog savjetovanja. Rezultati konfirmatorne faktorske analize podržavaju predloženi 9-faktorski model ovog upitnika. Ovim instrumentom omogućeno je mjerenje širokog raspona kognitivnih strategija emocionalne regulacije jednim upitnikom. Mjerenje tih strategija pritom može otkriti ranjivosti ili snage pojedinca u nošenju s negativnim životnim događajima te se može korisno upotrijebiti u planiranju psihoterapijskih intervencija (osobito u području kognitivno-bihevioralnih terapija).
\end{abstract}

Ključne riječi: kognitivna emocionalna regulacija, kognitivno suočavanje, Upitnik kognitivne emocionalne regulacije - skraćeni oblik

\section{UVOD}

Emocionalna regulacija jedan je od važnih čimbenika koji određuje psihološku dobrobit, odnosno ima važnu ulogu u prilagodbi na stresne životne događaje (Eisenberg, Fabes, Guthrie i Reiser, 2000; Cicchetti, Ackerman i Izard, 1995). Gross (1998) definira emocionalnu regulaciju kao procese pomoću kojih pojedinci utječu na to koje će emocije doživjeti, kada će ih doživjeti i kako će ih izraziti. Prepoznavanje i razumijevanje vlastitih emocionalnih iskustava temelj je regulacije koja uključuje procese nadgledanja, procjene i modificiranja emocionalnih reakcija. Re- 
zultati dosadašnjih istraživanja upućuju na to da emocionalna regulacija dovodi do promjena u dinamici emocija jer utječe na pojavu, intenziviranje, održavanje i ublažavanje reakcija na iskustvenom, ponašajnom i fiziološkom planu (Gross, 2002).

Općenito, emocijama se može upravljati kroz cijeli raspon nesvjesnih kognitivnih procesa (npr. procesi selektivne pažnje, iskrivljenje pamćenja, poricanje, projekcija), što podrazumijeva jednostavno registriranje osjetnih informacija koje aktiviraju kognitivne strukture, a koje dalje djeluju na emocionalne reakcije pojedinca. Svjesna emocionalna regulacija aktivira proces pažnje, voljna je i vođena određenim ciljevima (Mauss, Cook i Gross, 2007), a uključuje npr. okrivljavanje sebe, okrivljavanje drugih, ruminaciju ili katastrofiziranje. Iako je kapacitet za unaprijeđeno mišljenje i regulaciju emocija kroz kognicije univerzalan, postoje velike individualne razlike u količini kognitivne aktivnosti i u sadržaju misli kroz koje ljudi reguliraju svoje emocije kao odgovor na životna iskustva, događaje i stresore. Moguće je da ovaj namjerni proces s vremenom može postati automatski (Mauss i sur., 2007). Iako je opisani konstrukt vrlo koristan kao teorijski opis ili objašnjenje sustava emocija, cjelokupni proces emocionalne regulacije je presložen i preširok da omogući istodobno empirijsko usmjeravanje na sve aspekte, mehanizme i procese.

Emocionalna regulacija u uskoj je vezi s konstruktom suočavanja, pa se tako u nekim istraživanjima termini "kognitivno suočavanje" i "kognitivna emocionalna regulacija" koriste kao istoznačnice (Garnefski, Kraaij i Spinhoven, 2001; Garnefski i Kraaij, 2007) jer oba pojma predstavljaju kognitivni način upravljanja emocionalno pobuđujućih informacija. Lazarus (1993) opisuje suočavanje kao "stalne kognitivne i bihevioralne pokušaje upravljanja specifičnim vanjskim i/ili unutarnjim zahtjevima koji su procijenjeni teškima ili prezahtjevnima za resurse pojedinca". Moguće je razlikovati dvije glavne funkcije suočavanja: suočavanje usmjereno na problem i suočavanje usmjereno na emocije. Dok se strategije suočavanja usmjerene na problem odnose na pokušaje utjecanja na stresor, suočavanje usmjereno na emocije odnosi se na pokušaje upravljanja emocijama povezanih sa stresorom. Iako je Lazarusov pristup, temeljen na operacionalizaciji suočavanja kroz razlikovanje strategija suočavanja usmjerenih na problem i strategija suočavanja usmjerenih na emocije, široko prihvaćen i većina mjera suočavanja se temelje na njemu, prema mišljenju skupine nizozemskih autora (Garnefski i sur., 2001; Garnefski, Van den Kommer, Kraaij, Teerds, Legerstee i Onstein, 2002), nije primjereno rangirati koncepte kognitivnih i bihevioralnih strategija suočavanja u jednu te istu dimenziju, budući da je razumno pretpostaviti da procesi kognitivne procjene, iako ne nužno na svjesnoj razini, prethode procesima poduzimanja akcije (prvo se "prave planovi za poduzimanje akcije", a poslije toga je "akcija poduzeta"). Stoga je, iz perspektive intervencije, puno korisnije naučiti ljude da planiraju svoje akcije i posljedično se ponašaju svjesno na određeni način nego ih naučiti da poduzimaju trenutne akcije bez usmjeravanja na prateće kognicije. Dakle, moguća je i drugačija podjela strategija suočavanja, odnosno podjela na kognitivne ("ono što mislimo") nasuprot bihevioralnim ("ono što radimo") strategijama. Kako bi se opisane strategije mjerile 
na konceptualno čišći način, što bi doprinijelo novim spoznajama o tome kako kognitivni procesi reguliraju emocije i kako to može utjecati na smjer emocionalnog razvoja, konstruirana su dva oblika Upitnika kognitivne emocionalne regulacije (CERQ; Cognitive Emotion Regulation Questionnaire) različite duljine (Garnefski i sur., 2001; Garnefski i Kraaij, 2006a), čije se čestice odnose na ono što mislimo, a ne ono što činimo nakon iskustva prijetećeg ili stresnog životnog događaja. Uz pomoć tih čestica moguće je odrediti rezultate sudionika na devet različitih subskala koje uključuju okrivljavanje sebe, okrivljavanje drugih, ruminaciju, katastrofiziranje, stavljanje u perspektivu, usmjeravanje na pozitivno, pozitivnu ponovnu procjenu, prihvaćanje i usmjeravanje na planiranje. U svrhu oblikovanja sadržaja upitnika, autori su koristili na teoriji utemeljen ili "racionalni" pristup. Strategija konstrukcije upitnika temeljila se na korištenju strategija suočavanja iz postojećih mjera suočavanja (De Ridder, 1997) uz odabir ili reformuliranje kognitivnih dimenzija, transformiranju strategija suočavanja koje nisu kognitivne u kognitivne dimenzije ili pridruživanju novih strategija na teorijskoj osnovi (Garnefski i sur., 2001). Autori navode dobru unutarnju pouzdanost, test-retest pouzdanost te faktorsku i konstruktnu valjanost instrumenta (Garnefski, Kraaij i Spinhoven, 2001), kao i diskriminativnu i konvergentnu valjanost (Garnefski i Kraaij, 2007). Npr. CERQ upitnikom moguće je razlikovati osobe sa i bez psihičkih poremećaja (Garnefski i sur., 2002) te uočiti razliku između kliničkih skupina s različitim problemima (Garnefski, Kraaij i van Etten, 2005).

Rezultati brojnih istraživanja pokazuju povezanost pojedinih strategija kognitivne emocionalne regulacije i emocionalnih poteškoća kao što su depresivnost, anksioznost, stres i ljutnja (Garnefski, Boon i Kraaij, 2003; Garnefski i Kraaij, 2006b, 2007; Garnefski i sur., 2001; Garnefski, Teerds, Kraaij, Legerstee i Van den Kommer, 2004; Jermann, Van der Linden, d'Acremont i Zermatten, 2006; Kraaij, Garnefski, Schroevers, Weijmer i Helmerhorst, 2010; Martin i Dahlen, 2005) te povezanosti subskala CERQ-a sa psihološkom dobrobiti među osobama različite dobi, onima sa i bez psihičkih poremećaja te na uzorcima žrtava i ljudi s različitim medicinskim stanjima (Garnefski, Grol, Kraaij i Hamming, 2009a; Garnefski, Koopman, Kraaij i ten Cate, 2009b; Garnefski i Kraaij, 2006b, 2012; Garnefski, Kraaij, Schroevers i Somsen, 2008; Garnefski i sur., 2002; Kraaij, Arensman, Garnefski i Kremers, 2007; Schroevers, Kraaij i Garnefski, 2008). Vezano uz pojedinačne strategije, pojačana uporaba strategija okrivljavanja sebe, katastrofiziranja i ruminacije dosljedno je povezana sa slabijom prilagodbom (Kraaij, Garnefski i Schroevers, 2009). Uporaba kognitivnih strategija usmjeravanje na planiranje i pozitivna ponovna procjena, s druge strane, u brojnim je istraživanjima pozitivno povezana $\mathrm{s}$ psihološkom dobrobiti (Garnefski i sur., 2004; Kraaij, Garnefski i Vlietstra, 2008). Dodatno, faktorskim analizama višeg reda izdvajaju se dva nadređena faktora: prvi se naziva adaptivne strategije i uključuje usmjeravanje na pozitivno, pozitivnu ponovnu procjenu, stavljanje u perspektivu i prihvaćanje, dok se drugi faktor naziva manje adaptivne strategije i uključuje subskale ruminacije, okrivljavanja sebe, okrivljavanja drugih i katastrofizacije (Garnefski i sur., 2001; Jermann i sur., 2006). 
Razvoj CERQ-a omogućio je opsežna, integrativna istraživanja o odnosu između strategija kognitivne emocionalne regulacije i mentalnog zdravlja, čime je uklonjen nedostatak većine ranijih istraživačkih tradicija unutar kojih nije bilo moguće izvesti zaključke o zajedničkoj ulozi odvojenih kognitivnih strategija u razvoju psihopatologije. Iz toga razloga CERQ je preveden na različite jezike i dobiveni rezultati pokazuju slične faktorske strukture u usporedbi s izvornim upitnikom. Naime, konfirmatorne i eksploratorne faktorske analize upućuju na 9-faktorsku strukturu i zadovoljavajuće pouzdanosti subskala (Cakmak i Cevik, 2010; Ehring, Fischer, Schnülle, Bösterling, Tuschen-Caffier, 2008; Garnefski i sur., 2002; Jermann i sur., 2006; Megreya, Latzman, Al-Attiyah i Alrashidi, 2016; Perte i Miclea, 2011; Zhu, Auerbach, Yao, Abela, Xiao i Tong, 2008). Međutim, validacija na uzorku perzijskih adolescenata, govori u prilog 4-faktorske strukture (Aminabadi, Dehghani i Khodapanahi, 2012).

Uz to, CERQ se vrlo često koristi kao trijažno sredstvo u kliničkom radu te kao pomoć pri planiranju intervencija u uvjetima psihoterapije. Budući da CERQ, u svojem duljem ili kraćem obliku, još nije preveden na hrvatski jezik, uočena je potreba za takvim postupkom, što je napravljeno u provedenom istraživanju. S obzirom na to da je korištenje ovog upitnika planirano u jednom drugom istraživanju, uz još nekoliko upitnika, na uzorku osoba s psihičkim poremećajima, zbog vremenskog ograničenja i specifičnosti problematike ispitanika, odlučili smo se za prijevod skraćenog oblika upitnika CERQ.

\section{METODA}

\section{Sudionici}

Ispitivanje je provedeno na uzorku od 206 sudionika prosječne dobi 37,19 godina $(S D=12,81$; raspon 19-68) među kojima je bilo 88 (42,7\%) muškaraca i 118 $(57,3 \%)$ žena. S obzirom na bračni status, 116 (56,3\%) sudionika je bilo u braku ili izvanbračnoj zajednici, njih $88(42,7 \%)$ uključivalo je samce, rastavljene osobe i udovce, dok 2 (1\%) osobe nisu navele svoj bračni status. Pritom su 4 (1,9\%) sudionika završila osnovnu školu, njih 107 (51,9\%) srednju školu, dok ih je $49(23,8 \%)$ završilo preddiplomski studij, $38(18,4 \%)$ diplomski te $7(3,4 \%)$ poslijediplomski studij, a $1(0,5 \%)$ osoba nije navela svoj obrazovni status. Budući da je sadržaj primijenjenog upitnika usko vezan uz moguću psihološku intervenciju te je poznato da su vještine suočavanja sastavni dio brojnih psihosocijalnih intervencijskih programa, svi su sudionici bili uključeni u individualnu ili grupnu psihoterapiju (unutar kognitivno-bihevioralnog, analitičkog ili geštalt terapijskog pristupa) ili u psihološko savjetovanje. Navedene psihoterapijske/savjetodavne usluge provođene su unutar studentskih savjetovališta u Splitu i Rijeci, KBC-u Split, udrugama bolesnika oboljelih od kroničnih bolesti te u nekoliko privatnih psihijatrijskih ordinacija, a provodili su ih psiholozi ili psihijatri. Poteškoće zbog kojih su sudionici tražili 
stručnu pomoć bile su vrlo različite: emocionalni problemi studenata (najčešće u smislu anksioznosti, depresivnosti, teškoća učenja), potom teškoće pri suočavanju s autoimunom kroničnom bolesti, pacijenti iz kliničke populacije s dijagnozama psihičkih poremećaja, osobe s bračnim problemima itd. Među sudionicima bilo je 140 $(68 \%)$ onih koji su usluge savjetovanja/psihoterapije primali manje od 6 mjeseci, $50(24,3 \%)$ ih je u terapiju bilo uključeno između 6 i 12 mjeseci, dok je $16(7,8 \%)$ sudionika u terapiju bilo uključeno dulje od 12 mjeseci.

\section{Postupak}

Istraživanje je provedeno unutar studentskih savjetovališta u Splitu i Rijeci, KBC-u Split, udrugama bolesnika oboljelih od kroničnih bolesti te u nekoliko privatnih psihijatrijskih ordinacija gdje su sudionici posjećivali psihoterapiju ili psihološko savjetovanje. Sudjelovanje u istraživanju bilo je dobrovoljno i anonimno, a prije ispunjavanja upitnika sudionici su upoznati s ciljem istraživanja. Sudionici su upitnike popunjavali individualno ili grupno (ako su sudjelovali u grupnoj psihoterapiji).

\section{Instrument}

Upitnik kognitivne emocionalne regulacije - skraćeni oblik (Garnefski i Kraaij, 2006a) je instrument za ispitivanje devet konceptualno različitih kognitivnih strategija za regulaciju emocija (navedenih u Tablici 1). Upitnik sadrži 18 tvrdnji. Svaka od devet subskala upitnika sastoji se od dvije tvrdnje koje se odnose na način na koji ljudi razmišljaju nakon iskustva prijetećeg ili stresnog događaja. Zadatak sudionika je da na skali Likertova tipa od 5 stupnjeva (1 - nikada, 5 - uvijek) procijene koliko često, nakon nekog neugodnog iskustva, koriste svaki od opisanih načina razmišljanja. Rezultat ispitanika na pojedinoj subskali se dobije zbrajanjem rezultata koji su postignuti na toj subskali (u rasponu od 2 do 10), na način da veći rezultat znači da osoba više koristi specifičnu kognitivnu strategiju. CERQ je upitnik samoprocjene koji se primjenjuje na osobama iznad 12. godine života, jer se smatra da osobe od te dobi imaju kognitivne sposobnosti za razumijevanje značenja tvrdnji. CERQ se može koristiti za mjerenje kognitivnih strategija koje predstavljaju individualni stil odgovora na stresne situacije, kao i za mjerenje kognitivnih strategija koje se koriste u suočavanju s određenim stresnim događajem ili situacijom, ovisno o prirodi istraživačkih problema. U ovom istraživanju ispitivali smo opći stil kognitivnog suočavanja. Za potrebe ovog istraživanja upitnik je preveden na hrvatski jezik od strane autorica, pri čemu je korištena metoda dvostrukog prijevoda. Usporedbom ovih prijevoda postignut je dogovor oko jedinstvenog konačnog prijevoda upitnika. Cronbachovi alfa koeficijenti pouzdanosti za oba oblika CERQ u dosadašnjim istraživanjima su prihvatljivo visoki. Najniži koeficijent pouzdanosti za CERQ-short 
Tablica 1. Opis devet subskala Upitnika kognitivne emocionalne regulacije

\begin{tabular}{|c|c|}
\hline Naziv subskale & Opis subskale i primjer tvrdnje \\
\hline Okrivljavanje sebe & $\begin{array}{l}\text { opterećenost vlastitom krivnjom u misaonom sadržaju (“Mislim da je pravi } \\
\text { uzrok u meni.") }\end{array}$ \\
\hline Okrivljavanje drugih & $\begin{array}{l}\text { misli koje uključuju prebacivanje krivnje na okolinu i okolnosti (“Mislim } \\
\text { da su drugi odgovorni za to što se dogodilo.") }\end{array}$ \\
\hline Ruminacija & $\begin{array}{l}\text { ponavljane misli o osjećajima i mislima povezanima s negativnim } \\
\text { događajem ("Zaokupljen sam time što mislim i osjećam zbog toga što se } \\
\text { dogodilo.") }\end{array}$ \\
\hline Katastrofiziranje & $\begin{array}{l}\text { misli o eksplicitnom naglašavanju užasa kojeg je osoba doživjela, odnosno } \\
\text { prenaglašavanje negativnih strana i posljedica uznemirujućeg događaja } \\
\text { ("Stalno razmišljam kako je strašno to što mi se dogodilo.”) }\end{array}$ \\
\hline $\begin{array}{l}\text { Stavljanje u } \\
\text { perspektivu }\end{array}$ & $\begin{array}{l}\text { umanjivanje važnosti događaja (“Kažem sebi da ima i gorih stvari u } \\
\text { životu.”) }\end{array}$ \\
\hline $\begin{array}{l}\text { Usmjeravanje na } \\
\text { pozitivno }\end{array}$ & $\begin{array}{l}\text { razmišljanje o nečemu ugodnom umjesto o stresnom događaju (“Mislim o } \\
\text { nečemu lijepome umjesto o toj situaciji.") }\end{array}$ \\
\hline $\begin{array}{l}\text { Pozitivna ponovna } \\
\text { procjena }\end{array}$ & $\begin{array}{l}\text { misli kojima se događaju pridaje pozitivno značenje u kontekstu osobnog } \\
\text { razvoja ("Mislim da mogu postati jača osoba nakon toga što se dogodilo.") }\end{array}$ \\
\hline Prihvaćanje & $\begin{array}{l}\text { misli o prihvaćanju onoga što se dogodilo (“Mislim da trebam prihvatiti } \\
\text { ono što se dogodilo.") }\end{array}$ \\
\hline $\begin{array}{l}\text { Usmjeravanje na } \\
\text { planiranje }\end{array}$ & $\begin{array}{l}\text { misli o tome koje korake treba poduzeti kako bi se upravljalo negativnim } \\
\text { događajem ("Planiram učiniti ono što najbolje mogu.") }\end{array}$ \\
\hline
\end{tabular}

nađen je za subskalu Okrivljavanje sebe $(0,67)$, a svi ostali koeficijenti pouzdanosti kreću se u rasponu od 0,73 do 0,81 (Garnefski i Kraaij, 2006a).

\section{REZULTATI}

\section{Svojstva čestica}

Na početku, za svaku pojedinu česticu izračunati su temeljni deskriptivni pokazatelji, odnosno aritmetička sredina i standardna devijacija te raspon, koji su prikazani u Tablici 2.

Korištenje Upitnika kognitivne emocionalne regulacije - skraćeni oblik kao mjere devet strategija suočavanja

U svrhu određivanja faktorske strukture Upitnika kognitivne emocionalne regulacije - skraćeni oblik, provedena je konfirmatorna faktorska analiza kojom je pro- 
Tablica 2. Deskriptivne karakteristike (aritmetička sredina $(M)$, standardna devijacija $(S D)$ i raspon (minimalna i maksimalna vrijednost) Upitnika kognitivne emocionalne regulacije - skraćeni oblik.

\begin{tabular}{ccccc}
\hline redni broj čstice & $M$ & $S D$ & $\min$ & $\max$ \\
\hline 1. & 3,56 & 0,91 & 1 & 5 \\
2. & 4,09 & 0,64 & 2 & 5 \\
3. & 3,40 & 0,82 & 1 & 5 \\
4. & 3,43 & 0,92 & 1 & 5 \\
5. & 3,49 & 0,91 & 1 & 5 \\
6. & 3,99 & 0,74 & 1 & 5 \\
7. & 3,02 & 0,69 & 1 & 5 \\
8. & 3,36 & 0,80 & 1 & 5 \\
9. & 3,86 & 0,67 & 1 & 5 \\
10. & 2,95 & 0,95 & 1 & 5 \\
11. & 3,00 & 0,76 & 1 & 5 \\
12. & 3,37 & 0,70 & 2 & 5 \\
13. & 3,17 & 0,85 & 1 & 5 \\
14. & 3,37 & 0,94 & 1 & 5 \\
15. & 3,63 & 0,73 & 2 & 5 \\
16. & 3,40 & 0,70 & 1 & 5 \\
17. & 3,88 & 0,72 & 2 & 5 \\
18. & 2,85 & 0,87 & 1 & 5 \\
\hline
\end{tabular}

vjereno slaganje podataka s pretpostavljenom faktorskom strukturom upitnika koja je opisana u Metodi. Prilikom procjene slaganja korišteno je više različitih mjera koji uključuju vrijednosti hi-kvadrat testa $(\chi 2)$ i hi-kvadrata korigiranog s obzirom na stupnjeve slobode ( $\chi 2 / \mathrm{df})$, indeks komparativnog pristajanja $(C F I)$, nestandardizirani Tucker-Lewisov indeks pristajanja (TLI), korijen iz prosječne kvadrirane pogreške aproksimacije (RMSEA) te standardizirani korijen iz kvadriranih reziduala (SRMR) (Byrne, 2001; Hu i Bentler, 1999; Schreiber, Nora, Stage, Barlow i King, 2006). Ukupno gledajući, dobiveni rezultati upućuju na zadovoljavajuće pristajanje podataka modelu. Naime, iako su inicijalni rezultati pokazali statistički značajan hi-kvadrat test $(\chi 2(99)=127,12, p=0,03)$, nakon provedbe korekcije s obzirom na broj stupnjeva slobode dobiven je zadovoljavajući omjer manji od $5(127,12 / 99$ $=1,28$ ) (Brown, 2006; Jackson, Gillaspy i Purc-Stephenson, 2009), što upućuje na pristajanje modela podacima. Nadalje, indeks komparativnog pristajanja i nestandardizirani Tucker-Lewisov indeks pristajanja koji se odnose na ukupnu količinu objašnjene varijance kod ovog su modela bili veći od granične vrijednosti od 0,90 $(C F I=0,963 ; T L I=0,943)$, dok su korijen iz prosječne kvadrirane pogreške aproksimacije i standardizirani korijen iz kvadriranih reziduala bili manji od preporuče- 
ne granične vrijednosti $0,06(R M S E A=0,037 ; S R M R=0,051)$. Ukupno gledajući, može se zaključiti kako dobiveni rezultati pokazuju zadovoljavajuće slaganje podataka s pretpostavljenim modelom, odnosno potvrđuju pretpostavljenu 9-faktorsku strukturu instrumenta (Slika 1).

Na kraju, rezultati ispitanika na devet subskala Upitnika kognitivne emocionalne regulacije - skraćena forma izračunati su kao ukupni zbroj procjena u okviru pripa-

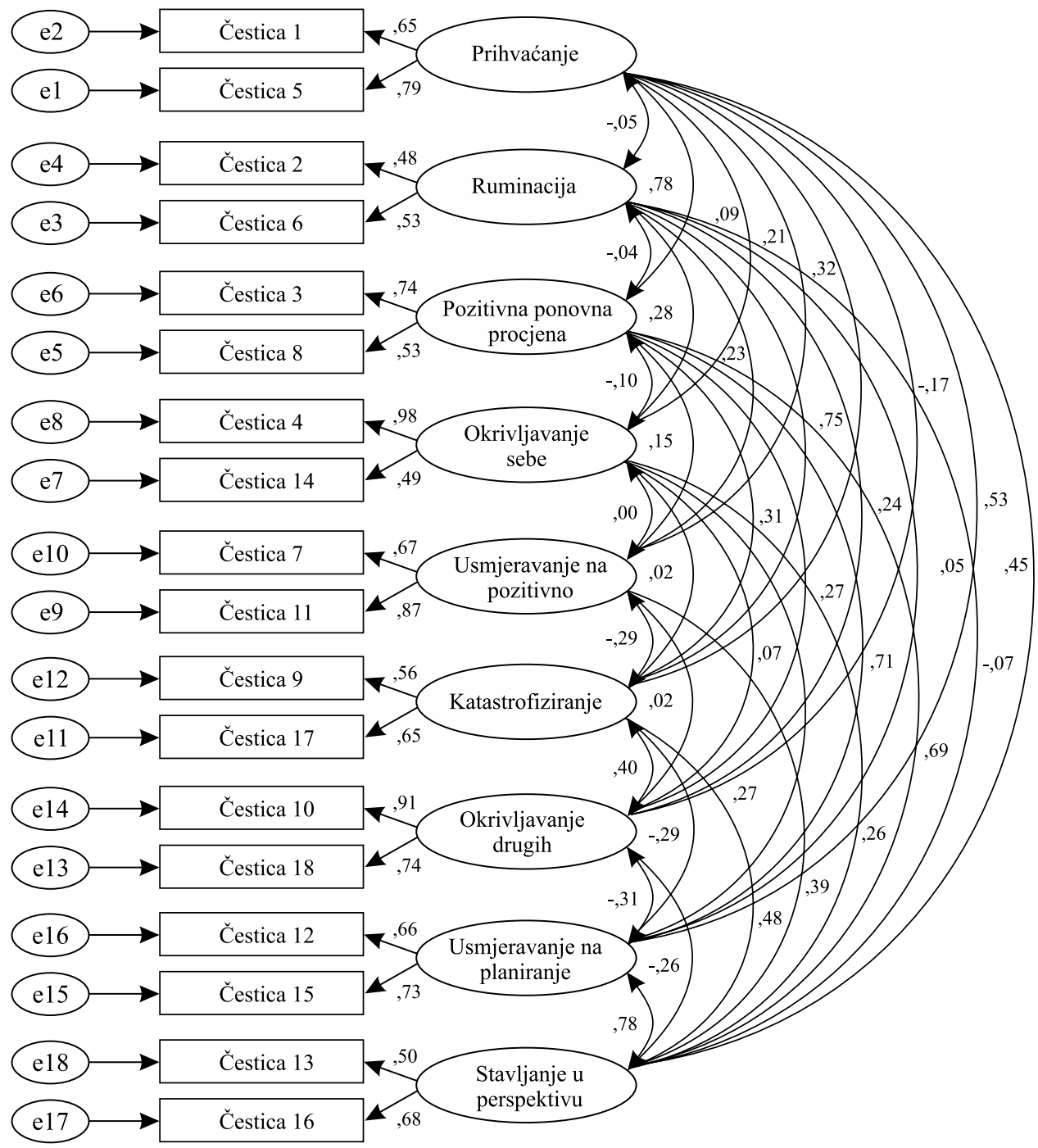

Slika 1. Rezultati konfirmatorne faktorske analize Upitnika kognitivne emocionalne regulacije-skraćeni oblik 


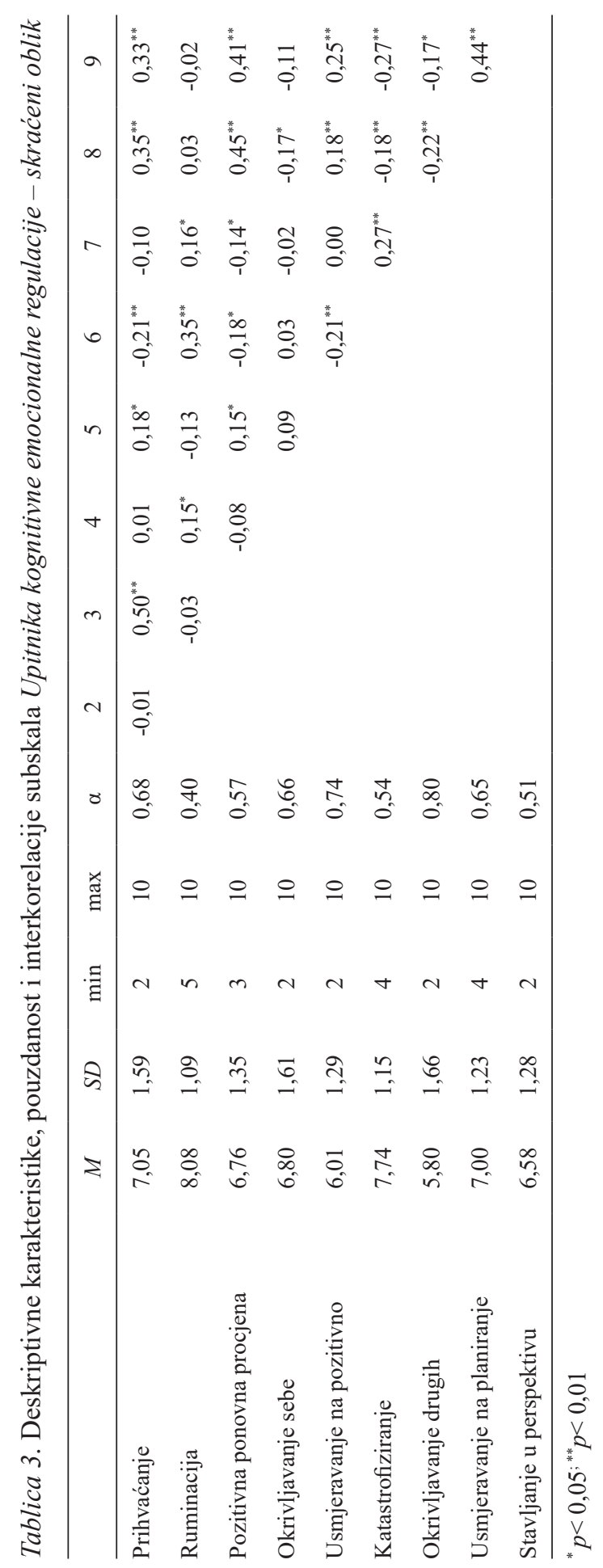


dajućih čestica prikazanih na Slici 1. Zatim su izračunati temeljni deskriptivni pokazatelji devet formiranih subskala i povezanost među pojedinim subskalama. Uz to, metodom interne konzistencije, odnosno određivanjem Cronbachova $\alpha$-koeficijenta izračunata je pouzdanost svake subskale (Tablica 2). Iako je nekoliko skala pokazalo zadovoljavajuće pouzdanosti, relativno niske vrijednosti $\alpha$-koeficijenta nekih od njih, prije svega skale ruminacije, posljedica su činjenice da se svaka subskala sastoji od samo dvije čestice. Stoga se u svrhu daljnjeg istraživanja psihometrijskih karakteristika pojedinih subskala predlaže ponoviti istraživanje na većem uzorku $i$ uz primjenu duljeg oblika CERQ-a.

Korištenje Upitnika kognitivne emocionalne regulacije - skraćeni oblik kao mjere adaptivnih i neadaptivnih pristupa suočavanju

Budući da se uočava međusobna povezanost pojedinih subskala, to opravdava grupiranje višeg reda. S obzirom na to da prethodna istraživanja pokazuju kako se pojedinačne strategije suočavanja mogu podijeliti na one adaptivne i neadaptivne, proveli smo konfirmatornu faktorsku analizu višeg reda kako bismo provjerili slaganje podataka s modelom koji pretpostavlja postojanje ova dva latentna faktora. Dobiveni rezultati upućuju na zadovoljavajuće pristajanje podataka modelu. Naime, iako su inicijalni rezultati pokazali statistički značajan hi-kvadrat test $(\chi 2(125)$ $=190,67, p<0,01)$, nakon provedbe korekcije s obzirom na broj stupnjeva slobode dobiven je zadovoljavajući omjer manji od $5(190,67 / 125=1,53)$ (Brown, 2006; Jackson i sur., 1993), što upućuje na pristajanje modela podacima. Nadalje, indeks komparativnog pristajanja i nestandardizirani Tucker-Lewisov indeks pristajanja kod ovog su modela bili veći od granične vrijednosti od $0,90(C F I=0,91 ; T L I=$ 0,90 ), dok su korijen iz prosječne kvadrirane pogreške aproksimacije i standardizirani korijen iz kvadriranih reziduala bili manji od preporučene granične vrijednosti $0,06(R M S E A=0,05 ; S R M R=0,07)$. Ukupno gledajući, može se zaključiti kako dobiveni rezultati pokazuju zadovoljavajuće slaganje podataka s pretpostavljenim modelom, odnosno potvrđuju da se originalnih devet faktora može grupirati na dva faktora višeg reda koji uključuju adaptivne i neadaptivne strategije suočavanja (Slika 2).

Nadalje, rezultati ispitanika na dva latentna faktora adaptivnih i neadaptivnih strategija Upitnika kognitivne emocionalne regulacije - skraćeni oblik izračunati su kao ukupni zbroj procjena u okviru pripadajućih čestica prikazanih na Slici 2. Zatim su izračunati temeljni deskriptivni pokazatelji dviju formiranih skala, kao i povezanost među pojedinim subskalama. Pritom je prosječni rezultat sudionika na Skali adaptivnih strategija iznosio 33,40 ( $S D=4,58$, raspon 18-49), a neadaptivnih 28,42 $(S D=3,30$, raspon 21-36), pri čemu je povezanost dviju skala iznosila $r(204)=-0,25, p<0,01$. Uz to, metodom interne konzistencije, odnosno određi- 


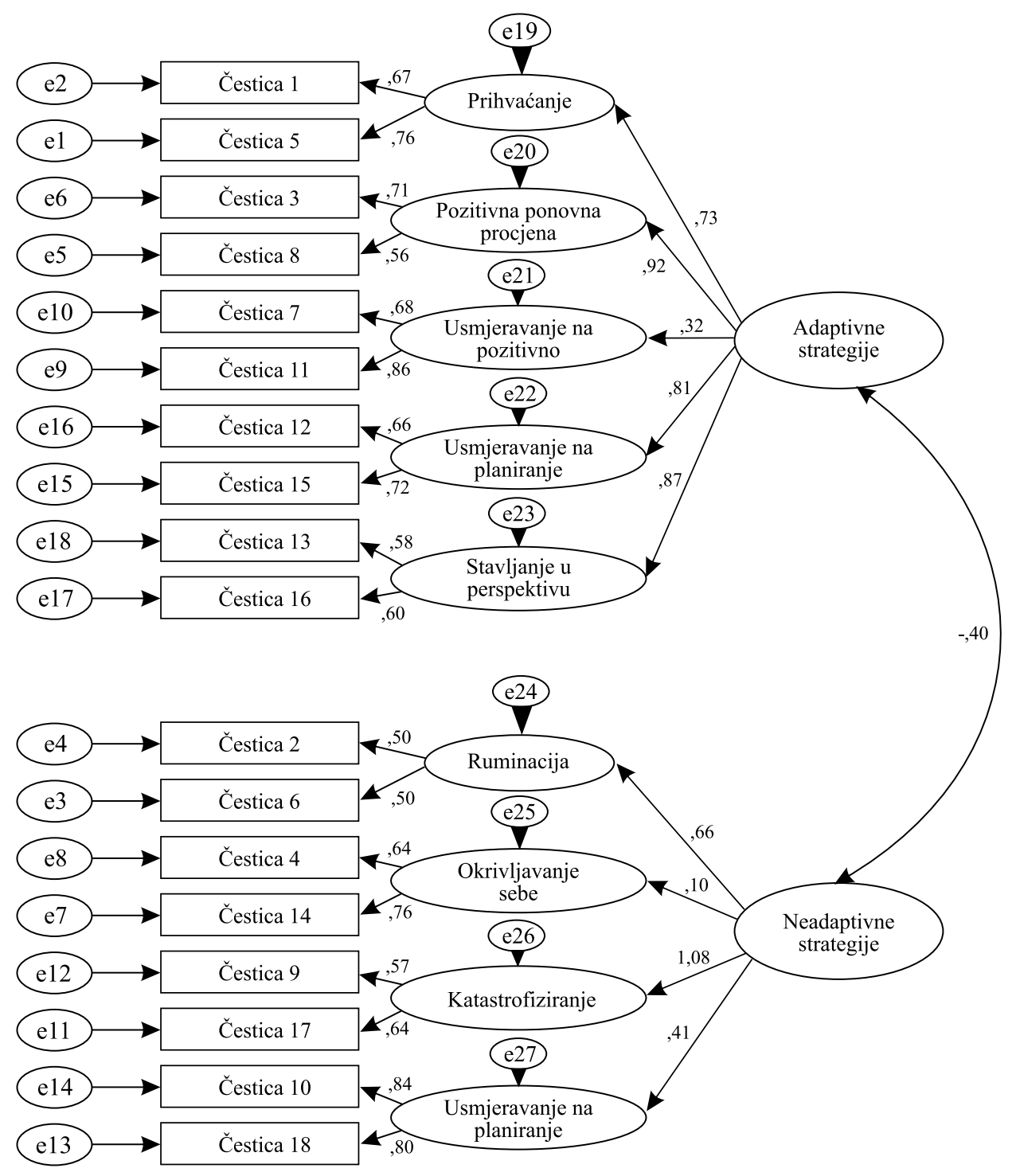

Slika 2. Rezultati konfirmatorne faktorske analize višeg reda Upitnika kognitivne emocionalne regulacije - skraćeni oblik

vanjem Cronbachova $\alpha$-koeficijenta izračunata je pouzdanost svake subskale, pri čemu je pouzdanost Skale adaptivnih strategija iznosila 0,78, a Skale neadaptivnih strategija 0,58 . 
Korištenje Upitnika kognitivne emocionalne regulacije - skraćeni oblik kao mjere općeg stila suočavanja

Nadalje, s obzirom na to da se Upitnik kognitivne emocionalne regulacije može koristiti kao mjera općeg stila suočavanja (Garnefski i sur., 2001), u ovom je istraživanju dodatno izračunat ukupni rezultat sudionika na cijeloj skali. Prije toga, rekodirane su procjene sudionika na česticama kod kojih veća procjena naznačuje razmišljanja vezana uz manje prilagođeno suočavanje (npr. "Stalno razmišljam kako je strašno to što mi se dogodilo"). Nakon toga izračunat je ukupni raspon rezultata na skali. Pritom se mogući raspon ukupnih rezultata na skali kretao u rasponu od 18 do 90 bodova, dok je dobiveni raspon iznosio od 34 do 76 bodova. Prosječna vrijednost postignuta na upitniku iznosila je $M=53,01$, a pripadajuće raspršenje $S D=6,28$. Pouzdanost cjelovite skale procijenjena je metodom interne konzistencije, odnosno određivanjem Cronbachova $\alpha$-koeficijenta pouzdanosti koji je iznosio 0,75.

\section{RASPRAVA}

Unutar provedenog istraživanja na hrvatski jezik je preveden Upitnik kognitivne emocionalne regulacije - skraćeni oblik te su provjerena neka njegova psihometrijska obilježja na uzorku polaznika psihoterapije ili psihološkog savjetovanja. Rezultati konfirmatorne faktorske analize podržavaju predloženi 9-faktorski model ovog upitnika te upućuju na to da se upitnik može koristiti i kao mjera adaptivnih i neadaptivnih strategija suočavanja (u skladu s rezultatima dobivenim u ranijim istraživanjima, npr. Jermann i sur., 2006).

Korištenje Upitnika kognitivne emocionalne regulacije - skraćeni oblik kao mjere devet strategija suočavanja

Općenito, Upitnik kognitivne emocionalne regulacije najčešće se koristi na način da se izdvoje pojedinačni faktori, odnosno strategije suočavanja prikazane u Tablici 3 (Garnefski i sur., 2001). Takva je praksa opravdana dosadašnjim istraživanjima koja su pokazala snažne povezanosti između upotrebe devet strategija kognitivne emocionalne regulacije i emocionalnih poteškoća.

Provedeno istraživanje također potvrđuje opravdavanost korištenja Upitnika kognitivne emocionalne regulacije kao mjere devet zasebnih strategija suočavanja sa stresom. Uočava se kako ispitanici koriste većinu strategija u rasponu od najmanje do najveće moguće vrijednosti, dok za strategije ruminacija i usmjeravanje na planiranje dolazi do blažeg smanjenja raspona. Također, naši su ispitanici relativno često koristili teorijski manje adaptivne strategije suočavanja (npr. ruminacija i katastrofizacija), što je dobiveno i u nekim ranijim istraživanjima (npr. Garnefski i sur., 2002; Nolen-Hoeksema, McBride i Larson, 1997; Perte i Miclea, 2011), a nešto rjeđe strategiju okrivljavanja drugih i usmjeravanje na pozitivno, što se dijelom 
može objasniti obilježjem uzorka koji su činile osobe s emocionalnim problemima koje su, moguće je, sklonije uporabi manje adaptivnih strategija suočavanja. Pritom treba spomenuti kako smisao i važnost korištenja skraćenog oblika skale kognitivne emocionalne regulacije dolaze iz njezine ekonomičnosti, odnosno pretpostavke o njezinoj upotrebljivosti kao instrumenta za brzu trijažu u kliničkim uvjetima i lakšeg uključivanja u velike istraživačke baterije samoprocjene kada postoji vremenska i/ili prostorna ograničenost.

Najveće ograničenje ovog istraživanja odnosi se na nešto niže pouzdanosti određenih subskala, npr. ruminacija, pozitivna ponovna procjena, stavljanje u perspektivu te skale neadaptivnih strategija, što se može dovesti u vezu s vrlo malim brojem čestica svake skale. Također, moguće je da ni uzorak u istraživanju nije primjereno ujednačen prema bitnim obilježjima (npr. moguće je da nisu dovoljno jasno definirani uvjeti i okolnosti psihoterapije/savjetovanja u kojima su sudjelovali naši ispitanici, te se, na taj način, možda ne može govoriti o međusobno usporedivim aktivnostima). Zato s ciljem provjere podataka, predlažemo ponovnu primjenu upitnika na drugom uzorku (npr. studenata ili osoba s psihičkim poremećajima) te $\mathrm{s}$ većim brojem ispitanika, kako bi se dodatno mogli protumačiti dobiveni nalazi i razjasniti nastali problemi. Zbog tih ograničenja, rezultati ovog istraživanja mogu se smatrati preliminarnima, sve dok ne budu ponovljeni u nekom budućem istraživanju. Ako ni tada podaci ne budu u većoj mjeri zadovoljavajući, preporuča se primjena dulje forme upitnika CERQ. Također se preporuča uključivanje i nekih vanjskih kriterija (npr. mjere anksioznosti, depresivnosti, psihološke dobrobiti i sl.) $\mathrm{u}$ ispitivanje kako bi se mogla ispitati kriterijska valjanost instrumenta i time proširiti postojeće spoznaje. Zaključno, specifičnosti hrvatskog prijevoda skraćenog oblika CERQ, u usporedbi s ranije navedenim podacima u drugim zemljama, očituju se u već spomenutim nižim pouzdanostima nekoliko subskala te se, u budućim istraživanjima, predlaže dodatno istražiti navedene nedostatke, $\mathrm{s}$ ciljem poboljšanja i daljnjeg primjerenog korištenja instrumenta.

\section{Korištenje Upitnika kognitivne emocionalne regulacije - skraćeni oblik} kao mjere adaptivnih i neadaptivnih pristupa suočavanju

Iako su u prethodnim istraživanjima pojedine strategije suočavanja najčešće istraživane odvojeno, važno je naglasiti da se neke od strategija međusobno mogu dovesti u vezu, što je vidljivo i u Tablici 3. Stoga je i prva konceptualizacija kognitivnih strategija Garnefske i suradnika (2001) pretpostavljala podjelu strategija na one više i manje adaptivne. To je potvrđeno i u istraživanju koje su proveli Jermann i suradnici (2006). U našem istraživanju provjerili smo mogućnost izdvajanja pretpostavljena dva latentna faktora, pri čemu su dobiveni rezultati pokazali kako se strategije suočavanja mogu grupirati u one adaptivne i neadaptivne. Pritom adaptivne uključuju: pozitivnu ponovnu procjenu, usmjeravanje na pozitivno, prihvaćanje, usmjeravanje na planiranje, stavljanje u perspektivu, a 
neadaptivne strategije uključuju: ruminaciju, katastrofiziranje, okrivljavanje sebe i okrivljavanje drugih.

Međutim, u razmatranju mogućnosti korištenja Upitnika kognitivne emocionalne regulacije kao mjere adaptivnih i neadaptivnih strategija važno je naglasiti kako ova podjela nije potvrđena u svim kasnijim istraživanjima. Osobito su miješani rezultati bili za subskalu prihvaćanje. Iako je prihvaćanje i empirijski (Garnefski i sur., 2001) i teorijski (Carver, Scheier i Weintraub, 1989) bilo opisano kao adaptivna strategija, neka istraživanja (Martin i Dahlen, 2005) pokazuju da ono može biti povezano s određenim psihološkim problemima kao što su depresija i stres. Objašnjenje može biti u pretpostavci o mogućnosti razlikovanja prihvaćanja kao aktivnog procesa samoafirmacije i prihvaćanja kao oblika rezignacije u odnosu na negativna iskustva (Wilson, 1996). Moguće je da navedeni rezultati više odražavaju drugi oblik prihvaćanja koji se često opisuje kao negativni stil prilagodbe povezan s lošijim ishodima. Ipak, u navedenim istraživanjima zaključuje se samo o povezanosti, a ne o uzročno-posljedičnim vezama, jer nije jasno jesu li specifične interpretacije negativnog događaja uzrok ili simptom depresivnosti i ostalih psihopatoloških stanja (Garnefski i Kraaij, 2006b). Također, i u našem istraživanju, polaznici psihoterapije i psihološkog savjetovanja za koje se može pretpostaviti da su više izloženi stresu (i, moguće, specifičnim psihopatološkim stanjima) od populacije koja nije uključena u navedene oblike pomoći, relativno često koriste prihvaćanje u suočavanju s negativnim životnim događajima.

\section{Korištenje Upitnika kognitivne emocionalne regulacije - skraćeni oblik} kao mjere općeg stila suočavanja

Iako je u prethodnim istraživanjima bilo uobičajenije zasebno određivati izraženost pojedinih strategija kognitivne emocionalne regulacije, Garnefski i sur. (2001) navode kako se Upitnik kognitivne emocionalne regulacije može koristiti i kao mjera općeg stila suočavanja. S obzirom na to, u ovom smo istraživanju također na ovaj način izračunali ukupne rezultate za svakog ispitanika. Unatoč zadovoljavajućim metrijskim karakteristikama, korištenje upitnika kao opće mjere suočavanja ne daje mogućnost detaljnijeg uvida u specifične kognitivne načine suočavanja koji se mogu korisno upotrijebiti pri planiranju individualnih terapijskih intervencija, osobito u okvirima kognitivnih terapija. Stoga se u kliničkoj praksi ne preporučuje ovakvo korištenje CERQ-a, dok u istraživanjima takvo korištenje može biti opravdano, ovisno o vrsti istraživačkih pitanja.

Implikacije za kliničku praksu

CERQ predstavlja jedan od danas vrlo često korištenih instrumenata za trijažnu procjenu u kliničkom radu koji se vrlo često može koristiti i prilikom planiranja 
psihoterapijskih intervencija. Naime, strategije suočavanja su osjetljive na kontekst i stresor, na način da u jednoj situaciji koristimo određene strategije suočavanja, a potpuno druge u drugim situacijama. Stoga možemo pretpostaviti da se kognitivne strategije suočavanja mogu mijenjati, odnosno da se one uče i da se na njih može utjecati, čak i ako su automatske, npr. kroz psihoterapiju (osobito kognitivno-bihevioralne orijentacije), programe intervencije ili osobno iskustvo pojedinca (Garnefski i Kraaij, 2007). U novije vrijeme, emocionalna regulacija se proučava kao moderator ishoda tretmana u različitim oblicima psihoterapije (npr. Wisco, Sloan i Marx, 2013). Dakle, znanje o tome koje strategije pojedinac koristi predstavlja područje za terapijsku intervenciju, a mjerenje pojedinčevih kognitivnih strategija može otkriti ranjivosti ili snage u nošenju s negativnim životnim događajima. Također, korištenje nekih strategija kognitivne emocionalne regulacije može biti važan pokazatelj ozbiljnih poteškoća te imati središnju ulogu u teorijskim modelima objašnjenja problema mentalnog zdravlja.

\section{LITERATURA}

Aminabadi, Z., Dehghani, M., Khodapanahi, M. K. (2012). Factor structure and validation of the Cognitive Emotion Regulation Questionnaire. Journal of Behavioral Sciences, 5(4), 365-371.

Brown, T. A. (2006). Confirmatory factor analysis for applied research. New York: Guilford.

Byrne, B. M. (2001). Structural equation modeling with AMOS: Basic concepts, applications, and programming. New York, NY: Psychology Press.

Cakmak A. F., Cevik, E. I. (2010). Cognitive emotion regulation questionnaire: Development of Turkish version of 18-item short form. African Journal of Business Management, 4(10), 2097-2102.

Carver, C. S., Scheier, M. F. i Weintraub, J. K. (1989). Assessing Coping Strategies: A Theoretically Based Approach. Journal of Personality and Social Psychology. 56(2), 267-283.

Cicchetti, D., Ackerman, B. P. i Izard, C. E. (1995). Emotions and emotion regulation in developmental psychopathology. Development and Psychopathology, 7, 1-10.

Clark, L. A., Watson, D. (1995). Constructing validity: Basic issues in objective scale development. Psychological Assessment, 7(3), 309-319.

De Ridder, D. (1997). What is wrong with coping assessment? A review of conceptual and methodological issues. Psychology and Health, 12, 417-431.

Ehring, T., Fischer, S., Schnülle, J., Bösterling, A., Tuschen-Caffier, B. (2008). Characteristics of emotion regulation in recovered depressed versus never depressed individuals. Personality and Individual Differences, 44, 1574-1584. DOI: 10.1016/j.paid.2008.01.013

Eisenberg, N., Fabes, R. A., Guthrie, I. K. i Reiser, M. (2000). Dispositional Emotionality and Regulation: Their role in Predicting Quality of Social Functioning. Journal of Personality and Social Psychology, 78, 136-157. 
Garnefski, N., Kraaij, V., van Etten, M. (2005). Specificity of relations between adolescents' cognitive emotion regulation strategies and Internalizing and Externalizing psychopathology. Journal of Adolescence, 28, 619-631. DOI: 10.1016/j.adolescence.2004.12.009

Garnefski, N. i Kraaij, V. (2006a). Cognitive emotion regulation questionnaire - development of a short 18-item version (CERQ-short). Personality and Individual Differences, 41(6), 1045-1053. DOI: 10.1016/j.paid.2006.04.010

Garnefski, N. i Kraaij, V. (2006b). Relationships between cognitive emotion regulation strategies and depressive symptoms: A comparative study of five specific samples. Personality and Individual Differences, 40, 1659-1669. DOI: 10.1016/j.paid.2005.12.009

Garnefski, N. i Kraaij, V. (2007). The cognitive emotion regulation questionnaire: Psychometric features and prospective relationship with depression and anxiety in adults. European Journal of Psychological Assessment, 23, 141-149. DOI 10.1027/10155759.23.3.141

Garnefski, N. i Kraaij, V. (2012). Cognitive coping and goal adjustment are associated with symptoms of depression and anxiety in people with acquired hearing loss. International Journal of Audiology, 51, 545-550. DOI: 10.3109/14992027.2012.675628

Garnefski, N., Boon, S. i Kraaij, V. (2003). Relationships between cognitive strategies of adolescents and depressive symptomatology across different types of life event. Journal of Youth and Adolescence, 32(6), 401-408. DOI: 10.1023/A:1025994200559

Garnefski, N., Grol, M., Kraaij, V. i Hamming, J. (2009a). Cognitive coping and goal adjustment in people with Peripheral Arterial Disease: Relationships with depressive symptoms. Patient Education and Counseling, 76, 132-137.

Garnefski, N., Koopman, H., Kraaij, V. i ten Cate, R. (2009b). Cognitive emotion regulation strategies and psychological adjustment in adolescents with a chronic disease. Journal of Adolescence, 32, 449-454.

Garnefski, N., Kraaij, V. i Spinhoven, P. (2001). Negative life events, cognitive emotion regulation and depression. Personality and Individual Differences, 30, 1311-1327.

Garnefski, N., Kraaij, V., Schroevers, M. J. i Somsen, G. A. (2008). Posttraumatic growth after a myocardial infarction: a matter of personality, psychological health, or cognitive coping? Journal of Clinical Psychology in Medical Settings, 15, 270-277.

Garnefski, N., Teerds, J., Kraaij, V., Legerstee, J. i Van den Kommer, T. (2004). Cognitive emotion regulation strategies and depressive symptoms: Differences between males and females. Personality and Individual Differences, 36, 267-276. DOI: 10.1016/S01918869(03)00083-7

Garnefski, N.,Van den Kommer,T., Kraaij, V., Teerds, J., Legerstee, J. i Onstein, E. (2002). The relationship between cognitive emotion regulation strategies and emotional problems: Comparison between a clinical and a non-clinical sample. European Journal of Personality, 16, 403-420. DOI: 10.1002/per.458

Gross, J. J. (1998). The emerging field of emotion regulation: An integrative review. Review of General Psychology, 2(3), 271-299.

Gross, J.J. (2002). Emotion regulation: Affective, cognitive, and social consequences. Psychophysiology, 39, 281-291. DOI: 10.1017.S0048577201393198

Hu, L. i Bentler, P. M. (1999). Cut off criteria for fit indexes in covariance structure analysis: Conventional criteria versus new alternatives. Structural Equation Modeling: A Multidisciplinary Journal, 6(1), 1-55. DOI: 10.1080/10705519909540118 
Jackson, D. L., Gillaspy Jr, J. A. i Purc-Stephenson, R. (2009). Reporting practices in confirmatory factor analysis: an over view and some recommendations. Psychological Methods, 14(1), 6-23. DOI: 10.1037/a0014694

Jermann, F., Van der Linden, M., d'Acremont, M. i Zermatten, A. (2006). Cognitive Emotion Regulation Questionnaire (CERQ): Confirmatory factor analyses and psychometric properties of the French translation. European Journal of Psychological Assessment, 22, 126-131. DOI: 10.1027/1015-5759.22.2.126

Kraaij, V., Arensman, E., Garnefski, N. i Kremers, I. (2007). The role of cognitive coping in female victims of stalking. Journal of Interpersonal Violence, 22, 1603-1612. DOI: $10.1177 / 0886260507306499$

Kraaij, V., Garnefski, N. i Schroevers, M. J. (2009). Coping, goal adjustment, and positive and negative affect in definitive infertility. Journal of Health Psychology, 14, 18-26. DOI: $10.1177 / 1359105308097939$

Kraaij, V., Garnefski, N. i Vlietstra, A. (2008). Cognitive coping and depressive symptoms in definitive infertility: A prospective study. Journal of Psychosomatic Obstetrics \& Gynecology, 29, 9-16. doi.org/10.1080/01674820701505889

Kraaij, V., Garnefski, N., Schroevers, M. J., Weijmer, J., i Helmerhorst, F. (2010). Cognitive coping, goal adjustment, and depressive and anxiety symptoms in people undergoing infertility treatment: A prospective study. Journal of Health Psychology, 15(6), 876-886.

Lazarus, R. S. (1993). Coping theory and research: past, present, and future. Psychosomatic Medicine, 55, 234-247.

Martin, R. C., Dahlen, E. R. (2005). Cognitive emotion regulation in the prediction of depression, anxiety, stress, and anger. Personality and Individual Differences, 39, 1249-1260. DOI: $10.1016 /$ j.paid.2005.06.004

Mauss, I. B., Cook, C. L. i Gross, J. J. (2007). Automatic emotion regulation during anger provocation. Journal of Experimental Social Psychology, 43, 698-711. DOI: 10.1016/j. jesp.2006.07.003

Megreya, A. M., Latzman, R. D., Al-Attiyah, A. A., Alrashidi, M. (2016). The robustness of the nine-factor structure of the Cognitive Emotion Regulation Questionnaire across four Arabic speaking Middle Eastern countries. Journal of Cross-Cultural Psychology, 47, 875-890.

Nolen-Hoeksema, S., McBride, A. i Larson, J. (1997). Rumination and psychological distress among bereaved partners. Journal of Personality and Social Psychology, 72, 855862.

Perte, A. i Miclea, M. (2011). The standardization of the cognitive emotion regulation questionnaire (CERQ) on Romanian population. Cognition, Brain, Behavior. An Interdisciplinary Journal, 15, 111-130.

Schreiber, J. B., Nora, A., Stage, F. K., Barlow, E. A., King, J. (2006). Reporting structural equation modeling and confirmatory factor analysis results: A review. The Journal of Educational Research, 99(6), 323-338. DOI: 10.3200/JOER.99.6.323-338

Schroevers, M., Kraaij, V., Garnefski, N. (2008). How do cancer patients manage unattainable personal goals and regulate their emotions? An examination of the relations between goal adjustment, cognitive emotion-regulation strategies, and positive and negative affect. British Journal of Health Psychology, 13, 551-562. DOI: 10.1348/135910707X241497 
Wilson, G. T. (1996). Acceptance and change in the treatment of eating disorders and obesity. Behavior Therapy, 27, 417-439.

Wisco, B. E., Sloan, D. M., Marx, B. P (2013). Cognitive Emotion Regulation and Written Exposure Therapy for Posttraumatic Stress Disorder. Clinical Psychology Science, 1(4), 435-442. DOI: $10.1177 / 2167702613486630$

Zhu, X., Auerbach, R.P., Yao, S., Abela, J. R. Z., Xiao, J., Tong, X. (2008). Psychometric properties of the Cognitive Emotion Regulation Questionnaire: Chinese version. Cognition and Emotion, 22, 288-307.

\title{
CROATIAN TRANSLATION OF THE COGNITIVE EMOTION REGULATION QUESTIONNAIRE - SHORT FORM
}

\begin{abstract}
The goal of this study was to develop the Croatian version of the Cognitive emotion regulation questionnaire - short form and assess its psychometric properties on a sample of 206 psychotherapy or psychological counselling users. Confirmatory factor analysis results confirm the suggested 9-factor model of this instrument. This questionnaire enables the measurement of a wide variety of cognitive strategies for emotion regulation with a single questionnaire. Measuring these strategies may reveal vulnerabilities or strengths of persons in coping with negative life events and can be useful in planning psychotherapy interventions (especially in the context of cognitive-behavioral therapies).
\end{abstract}

Key words: cognitive emotion regulation, cognitive coping, Cognitive Emotion Regulation Questionnaire - Short Form 